\title{
THE EMERGENCE OF STATE SPHERE IN SOCIAL MEDIA: A POLITICAL BALKANIZATION IN MALAYSIA
}

\author{
Badrul Azmier Mohamed@Bakar, Mohammad Agus Yusoff, Zawiyah Mohd Zain, Dori Efendi \\ School of History, Politics, and Strategy, Faculty of Social Science and Humanities, Universiti Kebangsaan \\ Malaysia, 43600 UKM, Bangi, Selangor, Malaysia \\ badrulmohamed@yahoo.com \\ School of History, Politics, and Strategy, Faculty of Social Science and Humanities, Universiti Kebangsaan \\ Malaysia, 43600 UKM, Bangi, Selangor, Malaysia \\ agus_ukm@yahoo.com
}

School of Government, College of Law, Government, and International Studies, Universiti Utara Malaysia, 06010 Sintok, Kedah, Malaysia zamzain@uum.edu.my

Fakulti Ekologi Manusia, Univiersiti Putra Malaysia, 43400 Serdang, Selangor, Malaysia doriefendi@yahoo.com

\begin{abstract}
Social media has phenomenally replaced the traditional media. Blogs have transformed news reporting; YouTube has reinvented talent sourcing; and "the trinity" (Facebook, Twitter, and YouTube) have revolutionary changed the rules of the game of regime change. Enabling commoners to be producers and its interactiveness are the two most important characteristics that grant the ordinary citizens to be extra-ordinary. From Tinseltown to Alexandria, the roles of social media has been unstoppably growing. The world political events in the recent times, particularly the Arab Spring have shown a strong correlation between social media and democratization. Malaysia's political experience in recent years, in particular the $12^{\text {th }}$ General Election (GE-12) in 2008 is comparable to the Arab Spring in view of the alluring role of social media and its gladiatorial impacts in politics. The failure of Barisan Nasional (BN or National Front, the only ruling party since independence) to retain its customary two-third majority in GE-12 is a proof of people's growing desire to enjoy democracy that among others offer free and fair elections, good-governance, and social justice which are dissimilar to existing communalism and strong government. At a glance, GE-13 in 2013 produced similar results as GE-12 which displayed fortification of democracy among citizens. In contrast, further analyses toward the details of GE-13 surfaced the revival of communalism and autoritarinism which have shown signs of decay in GE-12. Thus, this article explores the conflictual roles of social media which (has been functioning as an ideal public sphere) when the ruling party together with the state machinery invade the sphere of social media to satisfy their political agenda. This investigation showcases the anarchic sphere in social media is not only capable in catalyzing democratization, but also undermining democracy by propagating political Balkanization that propels disjointed feelings among multi-racial citizens.
\end{abstract}

\section{Indexing terms/Keywords}

Democratization, de-democratization, social media, elections, general elections

\section{Academic Discipline And Sub-Disciplines}

Political Science, Political Communication, Malaysian Politics, Elections

\section{SUBJECT CLASSIFICATION}

Political Science

\section{TYPE (METHOD/APPROACH)}

Library research, Literature analysis.

\section{Council for Innovative Research}

Peer Review Research Publishing System

\section{Journal: Journal of Social Sciences Research}

Vol. 5, No. 3 


\subsection{INTRODUCTION}

The success of Sarkozy in the $23^{\text {rd }}$ French presidential election (May 2001) has stirred attention towards the role of social media in politics. Sarkozy's campaign was equiped with Facebook and Twitter. On the other side of the Atlantic, the success of occupying the Oval Office after disappointing Clinton for Democrat's presidential candidacy and subsequently defeating McCain. The $56^{\text {th }}$ United States presidential election is another empirical evidence to support a hypothetical proposition of the increasing roles of social media in democracy. Obama success showcased a successful integration of social media in campaign exercises by engaging voters via Facebook, Twitter, and YouTube. As a result, Obama gained the highest number of ballots in the history of the United States presidential election. The success of Obama, an African American was comparable to John F. Kennedy's, a Catholic. Both charismatic non-WASP (White, Anglo-Saxon, Protestant) presidents' success were largely due to the advent of the emerging media in the respective era. Kennedy had successfully used television. Meanwhile, Obama's political engagement was made possible by social media. Apparently, social media has changed political games and political landscape worldwide.

The unanticipated falls of the stale but powerful Arab dictators like Ben Ali, Mubarak, and Gaddafi at the southern shores of Mediterranean put the world in shock. These northern African republics had regimes that were close to pure sultanism (Stepan \& Linz, 2013). The region lacks the foundation for democracy such as political apathy among society. The societies lack of strong civil societies; crippling market-based economy; low income and low literacy rate; undemocratic neighbors; and no experience in democracy (Bellin, 2004). Nevertheless, the incompatibility between Islam and democracy has always been animated as the other important barricade to the emergence of democratic societies in the region. Thus, democratization through mass revolution in fighting for democracy has been inconceivable in view of the mentioned interdependent factors. However, the pervasiveness of the series of uprisings that characterized the Arab Spring offers different views about the region in relation to democracy. The phenomena demonstrates social media as a public sphere conducive for non-state actors like dissenting movements that are usually comprised of the people, civil societies, and opposition parties. On the other side of aisle, the Arab Spring shows the impact of the absence of state in social media sphere.

\subsection{Background}

The advent of social media has expanded the public sphere in Malaysia. Traditional media such as radio, television, and newspapers have mainly been used by the state which mainly to the advantage of the ruling party. Blogs have made substantial impact to Malaysian politics before the emergence of Facebook, Twitter and YouTube. The results of the $12^{\text {th }}$ General Election (GE-12) in 2008 showed the important roles of blogs in democracy. The GE-12 denied the ruling party's customary two-third majority in Parliament that signalized the eroding appeal of communalism in Malaysia. As for the $13^{\text {th }}$ General Election (GE-13), the communal-based ruling coalition (which can be perceived as a multi-racial party due to its membership), Barisan Nasional (BN) that is comprised of parties that represents all races and ethnics in Malaysia (amongst the largest are; UMNO-United Malays National Organization, MCA-Malaysian Chinese Association, MICMalaysian Indians Congress, and Gerakan) was unsuccessful in the attempt to regain its two-third majority. In addition, the loss of four state governments to the opposition coalition, Pakatan Rakyat (People's Pact, PR) were unanticipated. The performance of PR was a result of political branding that advocated pro-democracy through rhetorics such as goodgovernance, social justice, human rights, and human security. On the surface, the outcomes of GE-12 indicated growing desire of multi-racial Malaysians to leave the old politics of communalism for the new politics of democracy. In relation to social media, the results of GE-12 showed the impact of the absence of the state in the sphere of social media.

Towards GE-13, BN was at the front row in using social media for political engagement in comparison to PR. Prime Minister Najib Razak has been more visible than the opposition leader Anwar lbrahim. Najib has more friends and followers than Anwar either in Facebook or Twitter. At a glimpse, the effects of the presence of the state (GE-13) are similar to its absence in the sphere of social media sphere (GE-12) whereby more and more voters voted for democracy. In contrast, the voting trend of GE-13 indicates the nation is racially polarized than it used to be in 2008 . The scenario arises questions pertaining the real outcomes of the state presence in social media sphere. Is the presence of the state in social media sphere leading Malaysia to further democratization or merely reinstating communalism which potentionally "Balkanized" the nation? Is social media just like another media which can be effectively used by the state in harnessing people's perception and political stance? Hence, this article is conceptually analyzing the extend of the comeback of communalism in relation to the emergence of state sphere in social media.

\subsection{Democracy, communalism and public sphere in Malaysia}

The practice of strong government manifested by single-party or hegemonic-party system has been shaping Malaysian public sphere. Allaying racial tension is the justification for media control. Thus, Malaysian citizens have never enjoyed free speech and expression like Western societies (Mohd Azizudin, 2010). "Repressive-responsive" and "neither authoritarian nor democratic" are two terms coined by Crouch (1996). "Syncretic state" (Jesudason, 1996), "coerciveconsociationalism" (Mauzy, 1995), "authoritarian populism" (Kua, 1995), "statist democracy" (Jesudason, 1995), "semidemocracy" (Case, 1993), "quasi democracy" and "illiberal democracy" (Zakaria, 1989), and "democracy without consessus" (Von Vorys, 1975) are the other terms describing the practice of democracy in Malaysia. "Asian model" and "enlightened democracy" are the other terms that help explaining Malaysian democracy, in which the ruling elites symbolize stability and predictability (Kukeyeva \& Shkapyak, 2013).

The state controls the media through existing availing laws. Despite people's growing resentment towards available repressive laws, most of them are still intact. Amongst them are; Seditious Act 1948, Internal Security Act 1960 (ISA), 
University and College University Act 1971 (AUKU), Official Secrecy Act 1972 (OSA), and Publication and Press Printing Act 1984 (301 Act), the act that specifically governs the media in Malaysia. Vividly, Provision 6, Section III of 301 Act authorizes the home minister to review any publication permits which may be resulted to either; renewal, modification to the terms of circulation, or; suspension, revocation, and awarding of license. Section $V$ of 301 Act acts to complement Section III in view of its functions to protect Home Minister from any legal proceedings initiated by any media operators that may experience losses due to the rulings or law enforcement by the state.

Apart from that, the media is controlled through state-ownership and ruling party's shareholdings. The national broadcasting agency, Radio Televisyen Malaysia (RTM) is under the authority of Ministry of Information, Communication, and Multimedia. RTM operates two television channels and multiple national and local radio stations. National news agency, BERNAMA is also placed under the same federal authority. Meanwhile, private television stations such as TV3, NTV7, TV9, and 8TV are operated by Media Prima Berhad, a media conglomerate which is closely related to the ruling party. Similarly, Astro, a main satellite-TV provider that monopolizes Malaysian subscribe-TV market.

In relation to the type of democracy in Malaysia, the traditional media is a sphere for the state than for the public. The state controls the media through legal provisions, state-ownership, and ruling-party related shareholdings. Hence, the traditional media is commonly used for the state-centric reporting. The news covers the opposing views is limited especially when it comes to elections, either general election or by-election. The state is pragmatic in crafting political rhetorics for media broadcasting, communal-based rhetoric is used not to the expense of national unity.

The increasing demand for democratization is in concert with the expansion of middle class which is the consequence of economic development. Najib's administration has been responsive and consequently disembarked on Political Transformation Program (PTP) with the abolishment of Internal Security Act in 2012. PTP is one of the three transformation programs. Government Transformation Program (GTP) and Economic Transformation Program (ETP) are the other two programs. The initiatives exhibit Najib's commitment to erase the image of "the government knows all" and to repudiate claim that his succession of premiership from Abdullah Badawi in 2010 as "the return of Mahathirism" that is synonymous to strong government, political stability, high-growth in economy. In contrast, the enactment of Public Assembly Act 2013 (PAA) was a backward step because it replaced ISA and contradicted to PTP's objectives. The legislation also signalized the growing concern of the state towards people's demand for democratization that may be increased the probability of changing regime through undemocratic means such as street protests. Thus PAA complements the roles of Communication and Multimedia Act 1998 (CMMA). The latter serves as a control device of the state in relation to the sphere of social media. The CMMA acts to barricade any political commotion online migrated to offline in the form of street protests and demonstration.

\subsection{The emergence of public sphere in social media of Malaysia}

The emergence of public sphere in social media of Malaysia can be traced back to the era of reformasi (reformation) which was an outcome of 1997 Asian Financial Crisis. Reformasi in Indonesia caused the fall of Soeharto, which opened avenues for democratization. In Malaysia, reformasi led the fall of Anwar Ibrahim (a prime minister in waiting), which cleared routes for democratization. Indonesia's democratization was revolutionary while Malaysia's process of democratization is evolutionary. Democratization through reformasi in Malaysia failed to produce any change of regime, but the civic movement successfully sparked popular interest towards democracy. Unlike the old politics of communalism, democracy emerged in an enticing package that consists of free and fair election, good governance, impartial judiciary and social justice that sound sophisticated and appeal universally.

Prior the era of reformasi, Malaysia experienced phenomenal economic development. Like many other East Asian countries, Malaysia embraced developmental state (Sity, 2004). Corporate nationalism, government linked companies (GLCs), and powerful state's investment arms prevail the roles of the state in economy of eastern societies. The state may not only interfere through fiscal measures, but also to the extend of participating in economy. The participative economic role of the state in East Asia differentiates itself from the traditional-liberal counterparts in the West. Towards the end of 1990's, Malaysia was hailed as one of "the tiger cub economies" together with Indonesia, Thailand, and the Philippines due to the consecutive years of double-digit economic growth. The Asian tigers trailed behind "the four liitle dragons" or the Newly Industrialized Countries (NICs) such as South Korea, Taiwan, Hong Kong, and Singapore. Developmental state has been at the base in transforming these East Asian countries including Malaysia from agragrian into industrial societies. The terms such as industrial-based, manufacturing-based, electronic-based, and export-driven may be used singularly or together in defining East Asian economies of 90's. The East Asian miracle was a conceptual product of the West but manufactured in the East. The miracle was a result of Western neo-liberal economic movement that advocated liberalization, deregulation, and privatization which ruin barriers and build interdepency. The industrialization was largely due to the foreign direct investments (FDIs) from the West and Japan that have been attracted to the cheap labors and resources in East Asia. However, the new model of economy has exposed Malaysia to ups and downs of global economy.

Petroleum revenue and state-initiated mega projects are not sufficient to complement manufacturing for sustainable economic growth. The expansion of middle class population has become a threat for an autocratic state. To develop further, Malaysia required economic diversification. Mahathir saw opportunities in information and communication technology (ICT) to accommodate Malaysia's changing society which experienced the increasing number of skilled labour forces. Mahathir founded Multimedia Super Corridor (MSC) and Cyberjaya smart-city that were blueprinted based on Silicon Valley in California. Mahathir visualized Malaysia as another hub for ICT industry in the East. In contrast to traditional media, the absence of state control is one of the main determinants that characterized social media sphere. Hence, in attracting investments from abroad to MSC and Cyberjaya, Malaysian government has delineated promises in 
protecting the anarchic trait of the internet in Malaysia which were comparable to the United States' First Amendment (Tan, 2010). The commitment showcases the pragmatic attitude of Malaysian government to uphold to the alienated principles of liberal-democracy for the sake of economic development.

Therefore, Malaysian cybersphere is congruent with Habermas' concept of public sphere in which the people could collectively form public opinion in atmosphere remote from the state and market. The ideal public sphere allows the citizens to interact, study, and debate on public issues without fear of reprisal from any political or economic powers (Beers 2006). Hence, in the span of ten years from 1998 (which denotes the fall of Anwar) to 2009 (that depicts the inception of Najib's administration), the state was absent from social media. Within the said period, the state merely opted to harassing instead of controlling the space when necessary. Hence, the anarchic climate of public sphere in social media is condusive for political discourse. The actors which have been denied participation offline have migrated online. In addition, information seekers who seeked alternative news reporting, browsing the internet and utilizing social media to fulfill their needs (Fischer, 2009). Hence, social media which has initially been desribed as an alternative media has been steadfastly replacing the role of the traditional media to Malaysian society.

Prior to 2009, the public sphere of social media was mainly populated by non-state actors especially the opposition parties, civil societies, and common citizens. In view of the internet, the state has mainly been focusing on the betterment of public service such as e-government. There are websites and blogs which have been critical to the state. The emergence of blogs operated by highly influential individuals like Abdul Kadir Jasin (a journalist turned blogger), Raja Petra (a social activist), and ex-premier Mahathir have created a phenomena. Blogs provide the grounds for greater news frame parity, multiple perspectives and alternative interpretations of decisions and events (Touri, 2009). Subsequently, the emergence of Web 2.0 has revolutionized communication in this public sphere that permits two-way and real-time communication. Thus, the political sphere in Malaysia falls into two categories; a state sphere (traditional media); and a public sphere (social media). Social media welcomes varied political information, political views, and ideas. The public sphere becomes a space to express dissatisfaction and grievance. Social media also provides a space for the emergence of imagined community. The concept mirrors a community which is dissatisfied with political condition of a polity; unfriendly towards the state especially the ruling elites; and engaging community members through printed media and printed capitalism (Anderson, 1983). Clearly, social media is a tool to support the formation and survivorship of any imagine communities at cyberspace (Tan 2010). In the context of Malaysia, this racially diverse community dreams; the emergence of a better nation in favor of democratization; strongly promoting good-governance and social justice; and distant away from communalism.

\subsection{The emergence of state sphere in social media of Malaysia}

The emergence of state sphere in social media of Malaysia is marked by the presence of state actors in GE-13 in 2013 . The political marketing efforts in social media by the ruling party, BN together with the state machinery denoted the state pragmatic attitude towards social media. Previously, the state opted to harassment that involved deployment of authorities instead of active participation which involved political marketing and political engagement. Najib succeeded Abdullah in April 2009 due to the unprecedented poor performance of Barisan Nasional in GE-12 which held in 2008. Vividly, the change of leadership led to the change of attitude towards social media. Najib has been an active user in Facebook and Twitter. Social media allows a person with authority to appear as "real person" and non-threatening (Marichal, 2012). The political engagement involved Facebook updates and Twitter microblogs. In 2010, Najib commenced an engagement program through Facebook called "mari berhubung mari bertemu" or "lets engage lets meet". To this date, Najib is statistically the most popular political figure in social media sphere with more than a million followers at Facebooks and Twitter. Consequently, the other ruling party leaders from many ranks followed suit to engage voters. Apart from the high ranking state leaders, like prime minister and cabinet ministers, the sphere of social media has also been populated by "cybertroopers" or the "keyboard warriors" who are usually bloggers hired by the ruling coalition (to be specific; UMNO, or United Malays National Organization, BN largest component party). The cybertroopers have been embracing provocativestyle writings that reap on personality bashing, character assassination, and playing racial cards. Apparently, the presence of state actors has transformed the atmosphere in social media of Malaysia that is inherently inclined towards the opposition and dissenting voices.

The proposition of the emergence of the state sphere in social media of Malaysia is further fortified by the implementation of political campaign efforts in massive scale. BN through the state machinery had undertaken political marketing exercises since 2009 in conjunction with the change of premiership. The political marketing exercises had been based on the transformational programs under "1Malaysia" rhetorics. To ensure the winning of BN in GE-13, the government spent the total amount of RM57.7 million (Welsh, 2013). The figure excerpted from the observations onto four thousand media reports dated from 2009 until April 2013. In addition, Nielsen Media Research surfaced the Prime Minister's Department expenditure for advertisement (that included marketing in social media) for March 2013 was skyrocketed at RM67.8 million which exceeded total expenses of companies like Nestle and Unilever (Zurairi, 2013). Political marketing undertook by the state to ensure the winning of Barisan Nasional was not only comprised of the usual strategy af airing patriotic songs and clips but also adopted celebrity endorsement that involved personalities such as singers, actors, sportsmen, television presenters, social activists and statemen. The aggressive and expensive campaigns in social media were based on "\#BetterNation" slogan. Barisan Nasional twitter account "@barisanasional" had been under the status of promoted account since May 2013. A minimum cost of USD15,000 (RM45,900) was required to promote a twitter account which may depend on the frequency of promotion. Nevertheless, similar political marketing exercises over traditional media were also taken place in social media. Banners and advertisements in many types and forms were strategically located and innovatively displayed in all over the sphere of social media. 


\subsection{Re-emergence of political Balkanization in Malaysia}

Political Balkanization is just another term for political polarization which may lead to breakups. The term is innovatively created and fundamentally based on the whole paradigm presented by Samuel P. Huntington in 1997; the clash of civilizations. In addition, the term "Balkanization" is epistemologically coined from the Balkan War held in early decade of 90's that witnessed the disintegration of Socialist Federal Republic of Yugoslavia. This part of Balkan peninsula became a case study for Huntington that partly hypothesized the clash of civilizations lead to disintegration of a nation. Yugoslavia was a nation-state formed after World War War II and lasted until 1992. The shared ethno-linguistic similarities supposed to bind the Serbs, the Croats, the Slovenes, the Bosniaks, the Montenegrins, and the Yugoslavs of Macedonia. Nationbuilding also was deemed uncomplicated in view of the small numbers of non-Yugoslavic ethnics such as Albanian in Kosovo and the Magyars in Vojvodina. Therefore, the breakups that began in 1992 was a result to the existence of varied civilizations in a single state. In Huntington's context, civilization is defined by religion which is claimed to be the core of culture. In other words, a "fault-line" state (another term under the umbrella of the clash of civilizations); a nation-state that may be diversed in terms of religion, culture, race, ethnicity, language, or sect is exposed to political polarization and probability of separation. Hence, Malaysia possesses all the attributes of a fault-line state. Basically, Malaysia is a multiracial state with population that professes variety of religions, and speaking in different languages. In the clash of civilizations terms, Malaysia is populated by four different civilizations; Islamic, Sinic, Hindu, and the West.

Prior to the Balkanization of the Balkan state of Yugoslavia into seven sovereign republics (which had taken placed from 1991 until 2008), a newly formed but racially polarized Federation of Malaysia had earlier Balkanized into two in 1965. For the sake of political stability, the Chinese majority state of Singapore emerged as a soverign Republic of Singapore. Communal-based politics has been rooted in Malaysian society since before the independence of Malaya and the formation Federation of Malaysia. A brief Japanese occupation from 1941 to 1946 is the main cause of racial disharmony (Cheah, 2012). The pro-Malay and anti-Chinese attitudes of the Japs initiated the racial tension in Malay Peninsula. However, the creation of a plural society or a society which was divided along communal lines in Malaya was a result of British Administration (Furnivall, 1948). In other words, a multiracial society of Malaya was a product of European colonialism which was once homogeneous. The demand for cheap labours from southern China and south India to work at tin mines and rubber plantations led to the heterogeinity of the land. Subsequently, the divide and rule policy of British Administration discouraged integration which contributed to the construction of communal-based identity which in time translated into communalism in politics. The prevalence of communal identity in the society have been inhibiting the construction of single national identity which later hurdled the process of nation-building and curtailed the emergence of Malaysian nationalism during the post-indepence era (Shamsul A. B., 1996). Nevertheless, communal issues were the main essence in choosing to the best form of state prior to the independence. Consequently, communal factors were institutionalized into the constitution of Malaya and later the constitution of Malaysia (Mohammad Agus Yusoff, 2006). The strong rejection of the proposed unitary system of Malayan Union by the majority Malays that later substituted with federalism system mirrored the influence of divisive communal-based politics prior to the indepence in 1957 and expansion of the federation in 1963. Article 152 and Article 153 of Malaysian Constitution that protect the interests of the natives and the Malays such as religion and language confirm the extend of communalism in Malaysia. Apparently, the existence of race-based or religious-based political parties is not the sole indicator of the strong influence of communalism in Malaysian politics. The two articles in the constitution confers patrimonial and parochial communal-based politics is the foundation of Malaysian politics that barricades the practice of democracy and democratization.

Malaysia in the post-Mahathir era has been more responsive and accommodative towards the pressure for democratization. During Abdullah's term (2003-2009), Anwar, the opposition leader was released from prison in 2004. Abdullah administration was also attentive to good-governance by emphasizing on inculcating integrity in Malaysian culture with the establishment of National Integrity Plan (PIN) and Malaysian Institute of Integrity in 2003. Abdullah further showed his commitment by "upgraded" Malaysian Anti-Corruption Agency (ACA) to Malaysian Anti-Corruption Commission (MACC) which was under direct authority of the executive. The commission has successfully placed under the legislative. Nevertheless, the social liberalization took the heat when for the first time in Malaysian history, leaders from both sides, the opposition and the government, were brought together on air on the same screen on a national television via a weekly series talk-show called "Hujah" (the debate) back in 2008 to 2009. The much talk about talk-show highlighted discourses (which mainly intellectual in nature) in current political issues in Malaysia which then turned an associate professor into a celebrity due to his sharpness and provocative-style in moderating the forum. Essentially, the phenomenal Hujah symbolized the openness of Abdullah administration that stimulated democratization to the nation. Similarly, Najib commitment for good-governance and democratization is shown through Government Transformation Program (GTP) and Political Transformation Program (PTP). The efforts are questionable, but the overall performance of both premiers in relation to democracy are better than the predecessor, Mahathir. Even though Mahathirism is best known for its not-sodemocratic strong government features, the autocratic-style of Mahathir has successfully transformed Malaysia into an industrialized society.

At a glimpse, the result of GE-12 in 2008 posited multi-racial Malaysians demanded for democracy and democratization. For the first time since $1969 \mathrm{BN}$ failed to secure its two-third majority in Parliament. In addition, BN also lost another four states namely Selangor, Perak, Penang, and Kedah to the opposition coalition (PR). The ruling party is identified relying on race-based politics through consociationalism (a term popularized by Lijphart) which manifested the power-sharing amongst races. However, communalism and consociationalism which have been proven effective for national stability and landslide majority in any election in Malaysia failed to produce the expected results. Hence, GE-12 was hailed as a "political tsunami" which mirrors the characters of the results which were unanticipated. Hence, it was believed that "new politics" of democracy and non-communal politics have just emerged in Malaysia. The series of 16 
post-political tsunami by-elections also indicated the fortification of new politics in Malaysia. Even though the results of the 16 by-elections between BN and PR were even; to the ratio of 1 to 1 , democracy seemed to be culturally rooted in the society that was once near-parochial and apathy. The series of by-elections were celebration of democracy with less and less trace of race. However, GE-13 brought back communalism to the limelight. Component parties of PR which strongly projected the image of pro-democracy before GE-13 have been increasingly sounding communal.

The most current polemics surrounding the position of Menteri Besar (chief minister) of the state of Selangor indicates communalism has strongly rooted in Malaysia. Selangor is under the control of an opposition coalition, PR that is comprised of PKR (People's Justice Party), DAP (Democratic Action Party), and PAS (Pan-Malaysian Islamic Party). PKR is the most democratic in view of its ideology and multi-racial membership. PKR might be the youngest in Malaysian political scene, but it has emerged as one of the strongest in Malaysia. DAP is ideologically democratic and opens membership to all citizens. However, the egalitarianism professed by the party is less appealing to the Malays. The ideology translated into membership which dominantly Chinese. It makes the party a Chinese party rather than a party for all Malaysians. PAS is a religious-based party, and very communalistic from every angle. Establishing an Islamic State and installing Hudud Law (or Sharia-compliance law) in multiracial Malaysia are their fundamental objectives. However, PAS have been lying low about Islamic State since prior to 1999 general election. Consequently, PAS decided to promote principles of democracy which condone to Islamic teachings such as good-governance and social justice. In the verge of GE-13, PAS came out with catchy but very meaningful slogan, "PAS for all". During GE-12 and GE-13 PAS highlighted the other sides of Islam which are alligned with good-governance, integrity, and justice. However, there was a swing votes from PAS to UMNO during GE-13 at rural constituencies which PAS have been depending on for decades. May be tactical, may be that is the real face of PAS, the party made a u-turn in dealing with the polemics Menteri Besar Selangor. If it was tactical, a communal PAS was deemed necessary to recapture Malay-Moslem confidence especially the rural Malays in the expense of democracy. Nevertheless, the behavior of PAS showed the infancy understanding about consociotionalism when interfered in PKR's affair of Menteri Besar candidacy and went to the extend of questioning eligibility of a candidate because of her gender. There were groups within PAS that questioned the alliance with DAP in particular merely because DAP is a non-moslem party. Political behavior of PAS opened up opportunities to the Sultan to intervene in executive and legislative matter which was not inline with the spirit of constitutional monarchy. The action of PAS indicates their aspiration to re-install caliphate system that infamously known for despotism and absolutism. Thus, communalism has reclaimed its position in Malaysian politics.

\subsection{Analysis}

Social media and individuals in Malaysia are inseparable. Gadgets for many individuals seem to be more important than family or friends. Instead of having real face-to-face conversation during any form of meetings, be it casual or formal, many opt to socialize via smart-phones and tablets. Consequently, this common social scene has been gradually accepted as a social norm in this part of the world. The burst popularity of social media is a product of deepening internet penetration which is partly due to the rapid development of ICT that has commenced during Mahathir era. Prior to the era of social media, the access to the internet were limited to the desktops and laptops. But today, rapid development in information and communication technology has permitted the mobile internet access via smaller, lighter, and edgier internet tools in the forms of smart-phones and tablets. The technological advancement has revolutionized the usage of social media in many aspects for different agenda. The process of producing, disseminating and sharing information has been radically transformed ever since. The communication is real-time, easy, and cheap. Meanwhile, the access can be at anytime, anywhere. Social media has been getting more political and consequently affecting Malaysian politics. Thus the scenario posits contesting questions. Is the presence of the state in social media sphere leading Malaysia to further democratization of Malaysia or reinstating racial poltics which Balkanized the nation? Is social media just like another media which can be effectively manipulated by the state in harnessing people's perception and stance?

The result of GE-12 is the outcome of the absence of the state in social media. Meanwhile the result of GE-13 is the yield of the active presence of the state in social media. The first analysis towards the findings provided by the result of GE-13 is based on the proposition that Barisan Nasional is the proponent of strong government that harping on communalism, and Pakatan Rakyat is the proponent of democratization that is distant from communal-based politics. Hence, the result of the GE-13 showcases that the multi-racial urban voters who are well-exposed to ICT voted for democratization. Therefore, the state presence in social media in towards the polling day on $5^{\text {th }}$ May 2013 failed to deliver the expected gain. The dominant ruling party only managed to win with a simple majority. To worsen, BN won the number of seats but lost in terms of popular votes. If GE-13 was a presidential election, Anwar has already been occupied the $5^{\text {th }}$ floor of Seri Perdana, Putrajaya (Prime Minister Office). From this perspective, the state sphere failed to dominate the sphere in social media due to the "innate" democratic attributes of social media such as its interactiveness, user-centered, almost anarchic. Nevertheless, the whole idea of social media, new media, the internet, and ICT that originate from the West is all about democratization of information and knowledge. Hence, based on the result of the GE-13 in 2013 , the emergence of state sphere in social media has failed to communalized Malaysian social media sphere and further Balkanized the nation.

However, the paradox surfaced in the aftermath of GE-13 with the success of UMNO in securing more seats, and the failure of the other BN component parties especially MCA (Malaysian Chinese Association) in retaining seats, poised another questioned. Without the coalitions, UMNO is the single largest party in the Parliament with 88 seats (securing additional 9 seats). The findings stated Malaysia communalism has made a comeback. The rural Malays and the Bumiputera (the indigenous) of Sabah and Sarawak opted to status-quo, and the non-bumiputera and urban an sub-urban Malays chose democratization. There are two situations to consider when come out with such analysis. Firstly, Malaysians in 2013 enjoyed better internet services such as speedier acces and wider coverage from arrays of more sophisticated 
devices in comparison to 2008. Secondly, the success of BN or (UMNO to be specific) in recapturing the state of Kedah and Perak, and retaining Terengganu. Therefore it seems there is a positive correlation between the existence of state sphere in social media with better performance of UMNO that had been operationalizing communalism to win GE-13. In view of the success of state in manipulating social media, the media seems to be just like traditional media. In which, the political campaigns that made appearance in newspapers, radio, and television such clips of songs, and informational campaigns were also relevant for social media, especially youtube which can be potentially viral all over the cybersphere.

The other questions arise. Did the non-Bumiputeras such Chinese and Indians who voted PR really voted for democracy? Did the young, urban, and educated Malays who voted the opposition coalition really free from communal agenda? In the verge of GE-13, both coalitions had been using "change" as a basis of their political rhetorics. Both had respectively identified themselves as the advocates of democracy and good-governance with promises of vertically and horizontally transform or reform the nation. However, further investigation and analyses over the activities online and offline of both political sides lead to different findings. At a glimpse, BN and PR were pursuing good-governance and democratic agenda. Yet, a deeper analysis shows, both have been entrapped by the old politics of communalism especially in capturing the confidence of voters in social media sphere. BN is not the only party that have been using the service of cybertroopers. PR has been depending on keybord warriors long before BN. Such scenario can be traced back to the era of reformasi due to the fact that traditional media have been a state sphere than a public sphere. Some cybertroopers may be hired and some may be volunteers.

Thus observations at the sphere of social media indicated that both coalitions adopting similar political strategies and communication styles such as playing racial cards, manipulating religious sentiments, spinning facts and figures, and resorting to the dirty tricks of character assassination. Jesudason described Malaysia a syncretic state due to its conflicting behavior (Jesudason, 1996). Heufers (2002, p.40) summarized Malaysia operates at multi-dimensional level; mixing coercive elements with electoral and democratic procedures; propagates religion while pursuing secular goals; engages in ethnic mobilization while inculcating national feelings. Thus, the analysis of GE-13 provides a finding that the state is not the only syncretic actor in Malaysia. The state, the oppositions, and the voters have been facing the dilemma between race and nation. In terms of partisan politics, both coalitions are Machiavellians and multi-faceted. The rethorics of unity in democracy were only at the level of leadership instead of at cybertroopers level. In other words, BN and PR are still bound to the Balkanizing communal-based politics. To answer the arisen questions above. Apart from social justice, Chinese and Indians prefer democracy because it may liberalize the economy that will be translated into more economic opportunities with the relaxation of affirmative policies that have been benefiting the Bumiputeras. Meanwhile the Malays that support PR that is comprised of Islamist party, PAS may perceive democracy is a mean to crystallize the dream of creating an Islamic State that is a paradox to democracy due to its advocacy of expanding the role of state in society. However, members of both races, especially the educated agreed upon the need for good-governance and social justice. Islam promotes good-governance and opens economic opportunities for all.

\subsection{Conclusion}

In conclusion, state sphere in social media may aggravate communalism instead of encourage democratization and therefore may perform functions like traditional media which may be for democratization or Balkanization. In Malaysian context, communalism is strongly rooted and democracy is considerably new to the society. Deviating from the West, citizens of Asian countries tend to think of democracy in substantive term and less in procedural term which makes them less critical to the incumbent (Min-Hua, Yun-han, \& Yu-tzung, 2013). The perception also makes communalism survives Malaysia and made a comeback in GE-13. Furthermore, the probability of democratization is minimal in highly polarized societies (Huntington, 1984). The heterogeneity of Malaysian society mirrors the diversity of ex-Yugoslav states, or a "fault-lines" society (Huntington, 1997). However, the marriage of communalism and consociationalism within the framework of democracy has been successful in developing the country. Communalism is so far the main hindrance for creation of national identity and the practice of full-fledged democracy. However, consociationalism or power sharing has been functioning as a political leveller that ensuring equitable distribution of wealth amongst race and class, and the impacts have been horizontally and vertically transformed the nation. The prospect of democracy and further democratization is very high in Malaysia due to the adoption consociotionalism by the oppositions. PR provides another alternative for Malaysia and it provides strong basis for the emergence of two-party system as in the United States, and the United Kingdom. Culturally, Malaysia is on the right path towards becoming a full-fledged democracy even though communalism is still dominant. New media goes hand in hand with new politics and therefore multiculturalism which thus seem new to Malaysia. Meanwhile, the old media goes hand in hand with old politics of communalism which deem increasingly irrelevant. However, consociationalism has turned the "trending" multiculturalism which mainly advocated by the opposition coaltiton, PR, looks nothing new in Malaysia. Multicultural politics has been in practiced since the inception of the first coalition named Perikatan (the Alliance) before independence. Thus, Malaysia has been prepared for democracy for more than five decades. In conclusion, the emergence of state sphere in social media in GE-13 has Balkanized the society, but has failed to disintegrate the Federation of Malaysia. The nation keeps striving in unity in diversity. 


\section{REFERENCES}

[1] Anderson, B. 1983. Imagined communities: Reflections on the origin and spread of nationalism. London: Verso.

[2] Beers, D. 2006. The public sphere and online, independent journalism. Canadian Journal of Education 29(1), 109130.

[3] Bellin, E. 2004. The robustness of authoritarianism in the Middle East: Exceptionalism in comparative perspective. Comparative Politics 36, 139-157.

[4] Blaydes, L. \& Lo, J. 2011. One man, one vote, one time? A model of democratization in the Middle East. Journal of Theoretical Politics 24(1), 110-146.

[5] Case, W. 1993. Semi-democracy in Malaysia: Withstanding the pressure for regime change. Pacific Affairs 66(2).

[6] Cheah, B. K. 2012. Red Star Over Malaya: Resistance and Social Conflict During and After the Japanese Occupation of Malaya, 1941-46.

[7] Crouch, H. 1996. Government \& society in Malaysia. St. Leornads: Allen \& Unwin.

[8] Fischer, J. 2009. 'We shift channel when Mahathir appears': The political Internet and censorship in Malaysia. Akademika Journal of the Southeast Asia Social Science and Humanities 75. 43-64.

[9] Heufers, R. 2002. The politics of democracy in Malaysia. ASIEN 85. 39-60.

[10] Huntington, S. P. 1984. Will more countries become democratic? Political Science Quarterly 99(2), 193-218.

[11] Huntington, S. P. 1997. The clash of civilizations and the remaking of world order. New York: Touchstone Books.

[12] Jesudason, V. 1995. Statist democracy and the limits to civil society in Malaysia. The Journal of Commonwealth \& Comparative Politics 33(3), 335-356.

[13] Jesudason, V. 1996. The syncretic state and the restructuring of oppositional politics in Malaysia. In Rodan, G. (ed.), Political opposition in industrializing Asia. 128-160. London: Routledge.

[14] Kua, A. 1995. Authoritarian populism. London: MacMillan.

[15] Marichal, J. 2014. Facebook democracy: The architect of disclosure and the threat to public life. Political Science Quarterly.

[16] Mauzy, D. K. 1995. Malay political hegemony and 'coercive consociationalism'. In Mc Garry, J. \& O' Leary, B. (Ed.), The Politics of Ethnic Regulation: Case studies of Protracted Ethnic Conflicts. London: Routledge.

[17] Min-Hua, H., Yun-han, C., \& Yu-tzung, C. 2013. Popular understanding of democracy and regime legitimacy in East Asia. Taiwan Journal of Democracy 9(1), 147-171.

[18] Mohd Azizudin, M. S. 2010, Freedom of Political Speech and Social Responsibility in Malaysia. Bangi: UKM Press

[19] Mohammad Agus, Y. 2006. Malaysian Federation: Conflict or Consensus. Bangi: UKM Press

[20] Shirazi, F. 2010. The emancipatory role of information and communication technology: A case study of internet content filtering within Iran. Journal of Information, Communication \& Ethics in Society 8(1), 57-84.

[21] Sity, D. 2004. Globalisai dan negara pembangunan. Akademika Journal of the Southeast Asia Social Science and Humanities 64, 27-42.

[22] Shamsul, A. B. 1996. The construction and transformation of a social identity: Malayness and Bumiputeraness reexamined. Journal of Asian and African Studies (52).

[23] Stepan, A. \& Linz, J. J. 2013. Democratization theory and the "Arab Spring”. Journal of Democracy 24, 15-30.

[24] Tan, L. O. 2010. Dinamik ruang siber dalam gerakan reformasi di Malaysia. Bangi: UKM Press

[25] Touri, M. 2009. News blogs: Strengthening democracy through conflict prevention. Aslib Proceedings: New Information Perspectives 61(2), 170-184.

[26] Von Vorys, K. 1975. Democracy without consensus: Communalism and political stability in Malaysia. Princeton: Princeton University Press.

[27] Welsh, B. 2013. Buying support-Najib's ‘commercialisation' of GE13. Retrieved from http://www.malaysiakini.com/news/227713

[28] Zakaria, A. 1989. Malaysia: Quasi-democracy in a divided society. In Diamond, L., Linz, J. J., \& Lipset, M. S., (Ed.), Democracy in developing countries: Asia. Colorado: Lynne Rienner.

[29] Zurairi, A. (2013). BN berbelanja besar untuk kuasi ruang iklan. Retrieved from http://www.themalaysianinsider.com/litee/print/bahasa/bn-berbelanja-besar-untuk-kuasai-ruang-iklan/ 


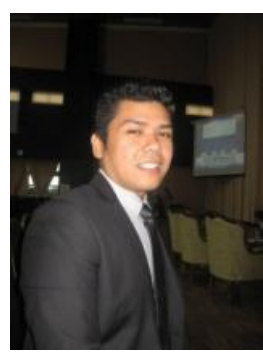

\section{Author' biography with Photo}

Badrul Azmier Mohamed@Bakar is a PhD. candidate in Political Science from Universiti Kebangsaan Malaysia (National University of Malaysia). He is pursuing a study on "Social Media in the $13^{\text {th }}$ General Election and Its Impact to Democratization in Malaysia." A multi-disciplined academician, he gained a degree in Bachelor of Science in Business Administration (Marketing and Human Resource Management) from Drexel University, Philadelphia, USA in 1997, and ten years later graduated from Universiti Kebangsaan Malaysia with Master of Arts in Political Science. A multi-talented individual; apart from full-time attachement with Universiti Teknologi MARA (UiTM) as a political science instructor, he is also an active trainer and speaker.

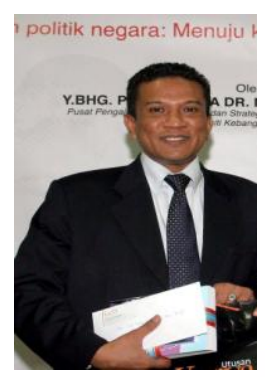

Associate Professor Dr. Mohammad Agus Yusoff is a Political Science lecturer from Universiti Kebangsaan Malaysia. He is an influential academician who is renown for his role as a talkshow/forum moderator and speaker. With more than 40 thousands Facebook followers, he is the only academician with a celebrity status in Malaysia.

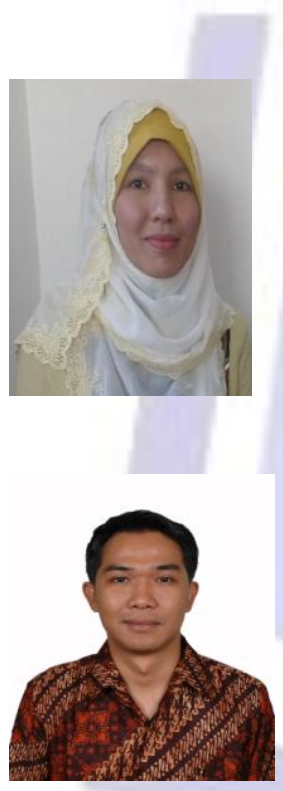

Dr. Zawiyah Mohd Zain is currently attached to Universiti Utara Malaysia (Northern University of Malaysia). Her research interests include Malaysian politics, democratization and civil disobedience.

Dori Efendi received a bachelor degree in the area of political science from Universitas Muhammadiyah, Yogjakarta, Indonesia and later gained a master degree from Universiti Kebangsaan Malaysia within the same field. He is currently pursuing a $\mathrm{PhD}$. research pertaining political development post 1997 Asian Financial Crisis in Indonesia and Malaysia at Universiti Putra Malaysia. 